\title{
EFFECT OF SOME FOLIAR APPLICATION ON YIELD AND ITS COMPONENTS IN BROAD BEAN (VICIA FABA L.)
}

\author{
MAGDI ANWAR NOSSER
}

Veg. Res. Dep., Hort. Res. Inst., ARC, Giza Egypt

(Manuscript received 12 May 2011)

\begin{abstract}
The field experiment was conducted during winter seasons of 2007/2008 and 2008/2009 at Barrage Horticultural Research Station, Kalubia Governorate, to study the performance of five broad bean cultivars, i. e., Reinamora, Luzudo Otono, Akoadolz, Ksaseen 7 and Sciabola Verde, and their response to some foliar application compounds, i. e ., Setter-2 $(1.5 \mathrm{~cm} / \mathrm{L})$, Oraset-x $(1 \mathrm{~g} / \mathrm{L})$ and Hyper-K $(2 \mathrm{~g} / \mathrm{L})$ The sprays were applied four times to fined out their effect on vegetative growth, behavior flowering, total yield, its components, pod characters and chemical contents.

Results indicated that significant differences were observed among the tested cultivars in plant height, number of branches/plant, number of days to flowering, nodes to first flower, setting percentage, total green yield and its components and chemical composition. The cultivar Reinamora was the most favorable for giving the best results in total green yield, number of pods/plant, number of seeds/pod, weight of 100 seeds and total protein. The foliar spray with Oraset-x followed by Setter -2 were significantly the superior treatments to produce plants with vigorous vegetative growth, $i$ e., plant height and number of branches/plant, earliness, highest fruit setting percentage, total green yield, number of pods/plant, weight of ten pods, pod characters, weight of 100 green seeds and total protein.

Significant differences were detected between cultivar and spray treatment interaction for plant height, number of branches/plant total green yield, weight of 10 pods, pod length and weight of 100 green seeds. Foliar spray with Oraset-x and Setter-2 treatment on Cv. Sciabola Verde gave the highest values of vegetative growth. However, spraying with both Oraset-x and Setter -2 on Reinamora cultivars increased total green yield, weight of 100 seeds.

Finally foliar spray with Oraset - $\mathrm{x}$ and Setter -2 on broad bean cultivars gave the best increase in fruit setting percentage, yield and its quality.
\end{abstract}

\section{INTRODUCTION}

Broad bean (Vicia faba L.) is one of the most important leguminous crops in winter in Egypt. Therefore such crop may respond well to foliar spray with some nutrition. The favorable effects of spraying nutrient solutions on plants is to improve pod quality and yield. 
The broad bean cultivars differ in plant height, flowering time, number of branches/plant, number of pods/plant, number of seeds/pod, pod weight, length, and width, as well as seed index and total green yield (Farag and Helal, 2004; Helal et al., 2005a). Abd Allah (2008) observed differ in six cultivars for plant height, number of branches/plant, number of pod/plant, pod length and pod yield.

The cultivars differ in number of nodes to flowering and potassium in the seeds (Patrick and Stoddard, 2010) and total protein in seeds (Crepon et al., 2010). Many workers were interested in using some nutrient substances to improved the yield and quality. Some workers using citric acids (Amer and El Assiouty, 2004) on pea reported that spraying plants with citrine (as a source of citric acid) increased seed yield, weight of 100 seeds and protein content. Shehata et al., (2007) found that the spraying with ascopen (ascorbic acid plus citric acid $38 \%$ ) on bean increased the yield. Helal (2005b) showed that application of ascorbic acid on pea increased total yield and pod characters. Kamal and Abd Al Gaid (2008) showed that spray with as ascorbic acid combined with both Vit. E and Salicylic acid increased plant growth, pod setting percentage, average weight of pod, number of seeds/pod, 100 green seeds weight and total pod yield of pea. Ali (2010) found that the foliar spray with citric acid increased fruit set percentage, total yield, seed quality and potassium. Another worker using Vitamin B. (Ahmed et al., 2006) on bean observed that spraying with vitamin B increased plant height, number of branches, number of pod/plant, total yield and total protein. Concerning using potassium, Abdel Aziz and Zakher (2010) found that foliar spray with faster substance (potassium $\mathrm{K}_{2} \mathrm{O} 30 \%$ ) gave the best treatments for total yield. As for using microelements, Helal et al. (2005a) on faba bean and Helal (2006) on snap bean reported that spray with some foliar microelements improved plant height, number of branches, earliness, total yield, weight of 100 seeds and chemical constituents of the green pods. Ewais (2010) spraying with some nutrients on snap bean increased the yield, pod quality and protein.

The aim of this work was to study the effect of some nutrients, i. e. setter-2, Oraset $\mathrm{x}$ and Hyper $\mathrm{K}$ to improve fruit setting percentage and yield on five broad bean cultivars.

\section{MATERIALS AND METHODS}

The field experiment was conducted during winter growing seasons of 2007/2008 and 2008/2009 at Barrage Horticultural Research Station, Kalubia Governorate, to evaluate the effect of some foliar substances to improve plant growth, flowering, setting percentage, total green yield and pod characters of five 
broad bean cultivars i. e. Reinamora, Luzudo Otono, Akoadoulz, Ksaseen 7 and Sciabola Verde. Four treatment were used in this study as a foliar spray as shown in Table (1).

Table 1. Names and sources of the compounds used in this study as a foliar spray.

\begin{tabular}{|c|c|c|}
\hline $\begin{array}{c}\text { Compound } \\
\text { names }\end{array}$ & Composition & Source \\
\hline $\begin{array}{l}1 \text { - Setter-2 } \\
(1.5 \mathrm{~cm} / \mathrm{L})\end{array}$ & $\begin{array}{l}5000 \mathrm{ppm} \text { ascorbic acid, } 1500 \mathrm{ppm} \\
\text { B,5000 ppm citric acid, } 1000 \mathrm{ppm} \\
\text { Mn,5000 ppm Total (N), } 1000 \mathrm{ppm} \mathrm{Cu} \text {, } \\
9000 \mathrm{ppm} \text { Chelated Ca. }\end{array}$ & $\begin{array}{l}\text { Union for Agricultural } \\
\text { Development, Egypt } \\
\text { (U. A. D) }\end{array}$ \\
\hline $\begin{array}{l}\text { 2- Oraset-x } \\
(1 \mathrm{~g} / \mathrm{L})\end{array}$ & $\begin{array}{l}\text { (a) } 1.5 \% \text { 2-(1-naphthyl) acetic acid } \\
\text { (b) } 0.45 \% \text { 2- Naphthoxy a cetic acid } \\
\text { (c) } 0.10 \% \text { Vit. B complex } \\
\text { (d) } 97.95 \% \text { Adjuvants \& carried } \\
\text { materials }\end{array}$ & $\begin{array}{l}\text { Arabian Group for } \\
\text { Agricultural service (A. } \\
\text { G. A. S) }\end{array}$ \\
\hline $\begin{array}{l}\text { 3- Hyper-K } \\
\text { (2g /L) }\end{array}$ & $60 \%$ potassium oxidase & $\begin{array}{l}\text { Union for Agricultural } \\
\text { Development, Egypt } \\
\text { (U. A. D) }\end{array}$ \\
\hline 4- Control & Tap water & \\
\hline
\end{tabular}

The foliar sprays were applied four times. The first was applied after 21 days from the sowing seeds. The second application was after 15 days from the first application, the third application was after 15 days from the second application and the last spray with the beginning of fruit set. The substances and the rate of spraying are illustrated in Table (1).

The treatments were assigned in split plot design with four replicates, in which broad bean cultivars were distributed in the main plots. Meanwhile, the foliar nutrition treatments were randomly arranged with sub plots. The plot area was $12 \mathrm{~m}^{2}$ included five rows each row was $4.0 \mathrm{~m}$ length and $0.6 \mathrm{~m}^{2}$ width. Seeds were sown on $14^{\text {th }}$ and $12^{\text {th }}$ of October in the first season and second season, respectively. The distance between plants was $20 \mathrm{~cm}$ apart, with one seed per hill. The other cultural practices were carried out according to the recommendation of the Ministry of Agriculture.

\section{Recorded data}

\section{Vegetative growth characters}

Ten plants from each plot were randomly chosen at the flowering stage, to determine plant height and number of branches/plant. 


\section{Flowering behavior}

Number of nodes until the first flower and number of days to first flower for $50 \%$ of plants in each plot were determined. Setting percentage was measured using 10 labeled plants in each plot according to the flowering equation,

Setting percentage $=\frac{\text { Total No. of pods/plant }}{\text { Total No. of flowers/plant }} \times 100$

\section{Yield and its components}

The pods were harvested at green maturity stage in all pickings and the total green yield was calculated.

4. Number of pods/plant : The average was taken from 5 plants.

5. Number of seeds/pod : Average number of seeds was recorded from ten pods.

\section{Pod characters}

A random sample of 10 pods for each plot was taken to determine average of pod weight, length, width and thickness.

\section{Weight of 100 seed}

\section{Chemicals composition of green seeds}

Mineral constituents were determined in the digested dry matter. Total nitrogen was determined using microkildahl according to Hesse (1971) and multiplying $\mathrm{N}$ values $\times 6.25$ to calculate total protein. $\mathrm{K}$ was determined using flame photometer according to Jackson (1967).

Data were subjected to statistical analysis according to Snedecor and Cochran (1980).

\section{RESULTS AND DISCUSSION}

\section{Vegetative growth characters}

\section{Effect of cultivars}

In Table (2) data reveal that there were significant differences in plant height and number of branches/plant in both seasons. Sciabola Verde among the five cultivars was the tallest plant followed by cv. Akoadolz while, cv. Ksaseen 7 was the shortest in the two growing seasons. Also, Sciabola Verde cultivar had more branching than the other cultivars in both seasons. The evidenced fact is that the plant growth is affected by genotypes, therefore, the studied cultivars differed significantly in growth characters. These results agree with those of Farage and Helal (2004) and Abd Allah (2008). They indicated that broad bean cultivars differ in plant height and number of branches/plant. 
Table 2. Effect of some foliar application on plant height, number of branches/plant, number of days to flowering and nodes to first flower for broad bean cultivars in $2007 / 2008$ and $2008 / 2009$ seasons.

\begin{tabular}{|c|c|c|c|c|c|c|c|c|}
\hline \multirow[t]{2}{*}{ Cultivars } & \multicolumn{2}{|c|}{$\begin{array}{l}\text { Plant height } \\
\quad(\mathrm{cm})\end{array}$} & \multicolumn{2}{|c|}{$\begin{array}{c}\text { Number of } \\
\text { branches/ } \\
\text { plant }\end{array}$} & \multicolumn{2}{|c|}{$\begin{array}{c}\text { Number of days to } \\
\text { flowering }\end{array}$} & \multicolumn{2}{|c|}{ Nodes to first flower } \\
\hline & $\begin{array}{c}2007 / \\
2008\end{array}$ & $\begin{array}{c}2008 / \\
2009\end{array}$ & $\begin{array}{c}2007 / \\
2008\end{array}$ & $\begin{array}{c}2008 / \\
2009\end{array}$ & $\begin{array}{c}2007 / \\
2008\end{array}$ & $\begin{array}{c}2008 / \\
2009\end{array}$ & $\begin{array}{c}2007 / \\
2008\end{array}$ & $\begin{array}{c}2008 / \\
2009\end{array}$ \\
\hline & & & \multicolumn{3}{|c|}{ Cultivars } & & & \\
\hline Reinamora (R) & 86.04 & 82.97 & 7.81 & 7.61 & 53.92 & 53.07 & 5.14 & 4.90 \\
\hline Luzudo Otono (L) & 80.68 & 81.23 & 7.43 & 7.03 & 52.75 & 51.24 & 4.64 & 4.71 \\
\hline Akoadolz (A) & 95.91 & 92.74 & 7.36 & 7.73 & 64.63 & 63.57 & 5.88 & 5.48 \\
\hline Ksaseen $7 \quad(K)$ & 71.91 & 71.72 & 6.20 & 6.11 & 58.23 & 55.71 & 5.43 & 5.04 \\
\hline SciabolaVerde(sv) & 104.59 & 97.97 & 9.16 & 9.88 & 65.69 & 62.08 & 6.51 & 6.68 \\
\hline L. S. D 5 \% & 2.12 & 2.21 & 0.28 & 0.36 & 1.44 & 2.45 & 0.26 & 0.29 \\
\hline & & & \multicolumn{3}{|c|}{ Treatments } & & & \\
\hline Setter-2 (S) & 91.50 & 86.56 & 8.07 & 7.79 & 56.84 & 54.88 & 5.46 & 5.31 \\
\hline Oraset-x (0) & 94.08 & 91.58 & 8.48 & 8.81 & 56.83 & 53.46 & 5.27 & 5.11 \\
\hline Hyper-k (H) & 87.15 & 84.76 & 7.43 & 7.45 & 59.40 & 58.16 & 5.57 & 5.37 \\
\hline Control & 78.58 & 78.39 & 6.39 & 6.65 & 63.10 & 62.04 & 5.79 & 5.67 \\
\hline \multirow[t]{2}{*}{ L. S. D 5\% } & 2.62 & 2.02 & 0.34 & 0.28 & 1.83 & 1.70 & 0.21 & 0.18 \\
\hline & \multicolumn{6}{|c|}{ Cultivars $\mathbf{x}$ Treatments } & & \\
\hline $\mathbf{R} \times \mathbf{S}$ & 88.1 & 84.92 & 8.60 & 7.55 & 50.70 & 50.40 & 4.98 & 4.63 \\
\hline $\mathbf{R} \times \mathbf{O}$ & 93.3 & 84.80 & 9.10 & 9.15 & 51.65 & 48.30 & 4.73 & 4.43 \\
\hline R X H & 85.23 & 83.53 & 7.50 & 7.45 & 55.03 & 54.5 & 5.38 & 5.13 \\
\hline $\mathrm{R} \times \mathrm{C}$ & 77.53 & 78.63 & 6.05 & 6.30 & 58.31 & 59.08 & 5.48 & 5.43 \\
\hline LXS & 82.18 & 82.75 & 7.78 & 7.03 & 51.29 & 49.93 & 4.48 & 4.75 \\
\hline LXO & 84.30 & 83.53 & 8.18 & 7.95 & 49.51 & 47.38 & 4.60 & 4.60 \\
\hline L X H & 79.53 & 80.83 & 7.43 & 7.05 & 53.84 & 52.00 & 4.65 & 4.65 \\
\hline LXC & 76.73 & 77.80 & 6.33 & 6.08 & 56.35 & 55.68 & 4.85 & 4.85 \\
\hline AXS & 96.1 & 90.70 & 8.15 & 8.33 & 63.03 & 61.80 & 5.60 & 5.43 \\
\hline A $\times 0$ & 103.98 & 99.95 & 8.13 & 8.40 & 62.98 & 60.80 & 5.70 & 5.40 \\
\hline A X H & 96.58 & 93.78 & 6.98 & 7.38 & 65.15 & 63.95 & 6.03 & 5.53 \\
\hline$A \times C$ & 87.00 & 86.55 & 6.18 & 6.83 & 67.35 & 67.73 & 6.20 & 5.60 \\
\hline KXS & 78.38 & 78.00 & 6.13 & 6.10 & 54.53 & 51.53 & 5.48 & 5.05 \\
\hline KXO & 77.48 & 79.55 & 6.48 & 6.43 & 55.56 & 51.03 & 5.34 & 4.88 \\
\hline K X H & 68.98 & 67.63 & 6.18 & 6.13 & 59.55 & 57.95 & 5.45 & 5.05 \\
\hline $\mathrm{KXC}$ & 62.83 & 61.70 & 6.03 & 5.80 & 63.28 & 62.33 & 5.45 & 5.20 \\
\hline sv Xs & 112.75 & 96.45 & 9.7 & 9.95 & 64.68 & 60.73 & 6.78 & 6.70 \\
\hline svxo & 111.35 & 110.08 & 10.5 & 12.10 & 64.43 & 59.78 & 5.98 & 6.25 \\
\hline S VXH & 105.45 & 98.18 & 9.05 & 9.23 & 63.43 & 62.42 & 6.33 & 6.50 \\
\hline s v XC & 88.83 & 87.25 & 7.38 & 8.25 & 70.22 & 65.40 & 6.95 & 7.25 \\
\hline L. S. D 5 \% & 5.85 & 4.52 & 0.77 & 0.62 & NS & NS & 0.43 & 0.41 \\
\hline
\end{tabular}




\section{Effect of foliar application}

Foliar application of Oraset-x followed by Setter-2 were more effective in increasing plant height and number of branches/plant compared with all other treatments (Table 2). This increase may be due to the content of those materials of ascorbic acid, acetic acid, citric acid

Vit. B. and microelement as well as some nutrients. Obtained results are in agreement with those reported by Helal (2006) and Kamal Abd Alla Gaid (2008).They indicated that the vegetative growth were significantly improved and higher by using foliar application of ascorbic acid and Vit. B. All treatments significantly improved all the studied vegetative characters relative to control in both seasons.

\section{Effect of interaction between cultivars and foliar application}

Data in Table (2) indicated that there were significant differences in plant height and number of branches/plant in both seasons. The highest values of plant height and number of branches/plant were obtained from all treatments foliar spraying on cv. Sciabola Verde compared with the other cultivars in both seasons.

The highest values of plant height and number of branches were showed by foliar application with Oraset-x treatment on Sciabola Verde cultivar followed by the treatment Setter-2 on Sciabola Verde cultivar in both seasons.

\section{Flowering behavior}

\section{Effect of cultivars}

Results in Table (2) show the variations among all the tested cultivars for number of days to flowering and number of nodes to first flower in both seasons. Luzdo Otono cultivar possessed a faster earliness and gave the lowest value of nodes to flower followed by $\mathrm{cv}$. Reinamora without significant differences between them. While, cv. Sciabola Verde was the latest to flower and had the highest number of nodes to flower in both seasons. The variation among cultivars in the earliness could be attributed to the genetic factors as reported by several workers (Farage and Helal, 2004; Partik; Stoddard, 2010).

\section{Effect of foliar application}

The results presented in Table (2) observed that Oraset-x treatment reduced the time spanned from planting to opening of the first flower and number of nodes to flower followed by Setter-2 treatment without significant differences between them in both seasons except number of nodes to flower in second season. While, control treatment took relatively a longer time of flowering and highest number of nodes to flower.

Such enhancing effect of foliar application on all flowering behavior may be attributed to the role of such nutrient on increasing plant growth, affective positively on 
flowering and in turn increased earliness. Obtained results are similar to those reported by Helal et al. (2005a) and Helal (2006).

\section{Effect of interaction between cultivars and foliar application}

Data in Table (2) show that there were no significant differences in number of days to flowering in both seasons. However, there were significant differences among all treatments and cultivars in number of nodes to first flower in both seasons. The lowest values of number of nodes to flower (earliness) were obtained from foliar spraying with all treatment on cv. Luzudo Otono compared with other cultivars in both seasons, The lowest values of number of nodes to flower was showed by foliar application with Setter - 2 treatment on Luzdo Otono in the first season. But in the second season, Oraset-x treatment on Reinamora gave the lowest value of number of nodes to flower.

\section{Fruit setting percentage}

\section{Effect of cultivars}

Results in Table (3) show the variations among all the tested cultivars for fruit setting percentage in both seasons. Reinamora cultivar gave the highest value of setting percentage followed by Luzudo Otono cultivar without significant differences between them in both seasons. The variation among cultivars in this trait could be attributed to the genetic factors.

\section{Effect of foliar application}

The results presented in Table (3) indicated that Oraset-x treatment increased setting percentage followed by Setter - 2 treatment without significant differences between them in both seasons. While, control treatment took relatively lowest value of setting percentage.

Such enhancing effect of foliar application on all flowering behavior may be attributed to the role of such nutrient on setting percentage. Obtained results are similar to those reported by Helal et al., (2005a), Helal (2006), Kamal and Abd Al Gaid (2008) and Ali (2010).

\section{Effect of interaction between cultivars and foliar application}

Data in (Table 3) show that there were no significant differences setting percentage in both seasons. 
Table 3. Effect of some foliar application on fruit setting percentage, total green yield, number of pods/plant and weight of 10 pods for broad bean cultivars in $2007 / 2008$ and $2008 / 2009$ seasons.

\begin{tabular}{|c|c|c|c|c|c|c|c|c|}
\hline \multirow[t]{2}{*}{ Cultivars } & \multicolumn{2}{|c|}{$\begin{array}{l}\text { Fruit setting } \\
\text { percentage } \\
\text { (\%) }\end{array}$} & \multicolumn{2}{|c|}{$\begin{array}{l}\text { Total green yield } \\
\text { (ton/fed.) }\end{array}$} & \multicolumn{2}{|c|}{$\begin{array}{l}\text { Number of } \\
\text { pods/plant }\end{array}$} & \multicolumn{2}{|c|}{$\begin{array}{l}\text { Weight of } 10 \text { pods } \\
\text { (g) }\end{array}$} \\
\hline & $\begin{array}{c}2007 / \\
2008\end{array}$ & $\begin{array}{l}2008 / \\
2009\end{array}$ & $\begin{array}{c}2007 / \\
2008\end{array}$ & $\begin{array}{c}2008 / \\
2009\end{array}$ & $\begin{array}{c}2007 / \\
2008\end{array}$ & $\begin{array}{c}2008 / \\
2009\end{array}$ & $\begin{array}{c}2007 / \\
2008\end{array}$ & $\begin{array}{c}2008 / \\
2009\end{array}$ \\
\hline & & & \multicolumn{3}{|c|}{ Cultivars } & & & \\
\hline $\begin{array}{l}\text { Reinamora } \\
\text { (R) }\end{array}$ & 49.84 & 48.98 & 14.175 & 13.363 & 26.59 & 24.91 & 346.76 & 341.69 \\
\hline $\begin{array}{l}\text { Luzudo Otono } \\
\text { (L) }\end{array}$ & 47.26 & 46.97 & 13.008 & 12.626 & 25.03 & 24.65 & 341.21 & 336.94 \\
\hline Akoadolz (A) & 45.68 & 43.98 & 10.138 & 9.813 & 20.68 & 20.27 & 151.21 & 148.29 \\
\hline $\begin{array}{l}\text { Ksaseen } 7 \\
\text { (K) }\end{array}$ & 42.88 & 43.70 & 7.600 & 7.481 & 14.98 & 14.66 & 111.40 & 109.51 \\
\hline $\begin{array}{c}\text { SciabolaVerde(s } \\
\text { v) }\end{array}$ & 45.68 & 44.37 & 12.125 & 11.763 & 19.16 & 18.35 & 350.10 & 347.52 \\
\hline L. S. D 5 \% & 2.57 & 2.49 & 0.46 & 0.48 & 0.86 & 0.93 & 3.72 & 5.40 \\
\hline & & & \multicolumn{3}{|c|}{ Treatments } & & & \\
\hline Setter-2 (S) & 49.35 & 48.28 & 12.160 & 11.825 & 22.62 & 21.44 & 268.99 & 264.36 \\
\hline Oraset-x (0) & 49.69 & 48.98 & 12.640 & 12.095 & 23.04 & 22.17 & 272.88 & 265.89 \\
\hline Hyper-k (H) & 47.06 & 47.08 & 11.235 & 10.915 & 20.29 & 19.97 & 257.86 & 256.57 \\
\hline Control (C) & 38.98 & 38.07 & 9.601 & 9.201 & 19.21 & 18.70 & 240.81 & 240.34 \\
\hline L. S. D 5\% & 2.53 & 2.88 & 0.36 & 0.26 & 0.73 & 0.99 & 2.93 & 3.92 \\
\hline & & & \multicolumn{4}{|c|}{ Cultivars $x$ Treatments } & & \\
\hline $\mathbf{R} \times \mathbf{S}$ & 54.32 & 53.89 & 15.611 & 14.400 & 27.85 & 24.23 & 349.68 & 347.35 \\
\hline $\mathbf{R} \times \mathbf{O}$ & 51.75 & 51.34 & 15.974 & 14.924 & 28.70 & 27.15 & 361.60 & 345.43 \\
\hline $\mathbf{R} \times \mathbf{H}$ & 50.01 & 51.85 & 13.823 & 13.750 & 25.13 & 24.03 & 349.30 & 349.30 \\
\hline $\mathbf{R} \times \mathbf{C}$ & 43.29 & 38.83 & 11.311 & 10.373 & 24.70 & 24.25 & 326.47 & 324.70 \\
\hline LXS & 51.19 & 50.21 & 14.074 & 13.875 & 26.05 & 25.37 & 350.07 & 345.90 \\
\hline LXO & 51.74 & 51.33 & 14.773 & 14.112 & 27.70 & 26.45 & 348.13 & 340.75 \\
\hline LX H & 47.17 & 46.36 & 12.713 & 12.476 & 23.75 & 24.32 & 339.53 & 337.43 \\
\hline LXC & 38.99 & 40.01 & 10.482 & 10.053 & 22.63 & 22.45 & 327.10 & 323.68 \\
\hline AXS & 49.11 & 45.64 & 10.275 & 10.225 & 22.00 & 21.30 & 164.53 & 156.58 \\
\hline$A \times 0$ & 50.21 & 46.92 & 11.368 & 10.778 & 21.60 & 21.03 & 168.57 & 162.25 \\
\hline A X $\mathrm{H}$ & 48.01 & 46.63 & 10.077 & 9.350 & 20.33 & 19.98 & 143.20 & 144.35 \\
\hline$A \times C$ & 35.40 & 36.75 & 8.88 & 8.912 & 18.80 & 18.78 & 128.53 & 129.98 \\
\hline KXS & 42.85 & 44.35 & 8.026 & 8.125 & 15.51 & 15.25 & 121.08 & 117.40 \\
\hline KXO & 46.18 & 47.01 & 8.050 & 7.950 & 15.88 & 15.80 & 122.88 & 120.10 \\
\hline K X H & 44.78 & 45.88 & 7.307 & 7.054 & 14.60 & 14.55 & 104.90 & 105.48 \\
\hline $\mathrm{K} \times \mathrm{C}$ & 37.72 & 37.58 & 7.025 & 6.828 & 13.93 & 13.05 & 96.75 & 95.05 \\
\hline svXs & 49.31 & 47.31 & 12.825 & 12.574 & 21.68 & 21.05 & 359.60 & 354.55 \\
\hline svXo & 48.58 & 48.33 & 13.023 & 12.724 & 21.33 & 20.43 & 363.25 & 360.95 \\
\hline SVXH & 45.33 & 44.69 & 12.278 & 11.965 & 17.65 & 16.98 & 352.38 & 346.30 \\
\hline S v XC & 39.51 & 37.17 & 10.375 & 9.842 & 15.98 & 14.95 & 325.18 & 328.28 \\
\hline L. S. D 5 \% & NS & NS & 0.80 & 0.59 & 1.64 & NS & 6.54 & 12.36 \\
\hline
\end{tabular}




\section{Yield and its components}

\section{Total green yield}

\section{Effect of cultivars}

Data in Table (3) showed that there were significant differences among all cultivars on total green yield and number of pods/plant. Total green yield of Reinamora cultivar was significantly the highest than all cultivars followed by Luzdo Otono cultivar in both seasons. Also Reniamora gave more pods/plant followed by Luzdo Otono in both season but with significant differences between them in the first season. These results agree with those of Farage and Helal, (2004), Helal et al. (2005a) and Abd Alla (2008). They found that the broad bean cultivars differ in total green yield.

\section{Effect of foliar application}

It could be concluded that total green pos/plant and number of pods/plant were significantly affected by the foliar treatments compared with the control in both seasons as shown in Table (3). Total green yield and number of pods/plant were significantly increased by foliar application of Oraset-x followed by foliar application of Setter-2 without significant differences between them in total green yield but with significant differences between them in number of pods/plant. These increases in total green yield and number of pods/plant may be due to the enhancing effect of those substances on vegetative growth improved flowering behavior and setting percentage. The enhancing effect of Oraset-x and Setter- 2 is may also be due to their containing of ascorbic acid, citric acid, acetic acid, Vit. B. and some elements (Table 1). The obtained results and interpretation are confirmed by findings of Amer and El Assiouty (2004), Ahmed et a: , (2006), Helal et al. (2005a), Helal (2006), Shehata et al. (2007), Abdel Aziz and Zakher (2010), Ali et al. (2010) and Ewais (2010). They showed that spraying leguminous plants with some nutrient substances increased total yield compared with the control treatment.

\section{Effect of interaction between cultivars and foliar application}

Significant differences were found for the interaction between cultivars and foliar application on total green yield in both seasons and number of pods/plant in the first season (Table 3).

Spraying with both Oraset $-x$ treatment and Setter -2 on Reinamora cultivar increased total green yield compared with other treatments in both seasons.

Concerning number of pods/plant, spraying with Oraset-x treatment on Reinamora gave the highest number of pods/plant followed by Setter-2 on the same cultivar and Oraset - $\mathrm{x}$ on Luzudo Otono but without significant different between them. 


\section{Weight of ten pods/plant and number of seeds/pod}

\section{Effect of cultivars}

Significant differences were observed in weight of 10 pods and number of seeds/pod, among the five tested broad bean cultivars as shown in Tables ( 3 and 4). Sciabola Verde cultivar tended to have higher weight of 10 pods and number of seeds/pod, followed by Reinamora for these traits in both seasons. The variation among cultivars in these traits could be due to the genetic factor. These results agree with those of Farage and Helal (2004), and Helal et al. (2005).

\section{Effect of foliar application}

Weight of ten pod was significantly increased by foliar application on Oraset-x treatment compared with the control treatment in both seasons, but number of seeds/pod was significant, only in the first season. (Tables 3 and 4). It is evident that all tested treatments improved these traits. These results agree with those of Kamal and Abd Gaid (2005) and Ali (2010). They found that spraying leguminous plants with some nutrient substances improved these traits compared with the control treatment.

\section{Effect of interaction between cultivars and foliar application}

Data in Tables (3 and 4) showed that significant differences were found for cultivars and foliar application interaction on weight of ten pods in both seasons. On the other hand no significantly differences in number of seeds/pod, were detected. Foliar spraying with Oraset-x treatment with Sciabola Verde gave the heaviest weight of ten pods followed by Reinamora cultivar with Oraset - $x$ in the first season. While in the second season, Sciabola Verde cultivar with Oraset $-x$ gave the highest value followed by Reinamora with Hyper-k.

\section{Pod characters}

\section{Effect of cultivars}

Significant differences were observed in pod length, thickness and width among the five tested broad bean cultivars as shown in Table (4). Sciabola Verde cultivar tended to have highest pod length, width and thickness followed by Reinamora for these traits however,

Differences among cultivars were noticed for pod characters by Farage and Helal (2004), Helal et al. (2005a) and Abd Allah (2008). 
Table 4. Effect of some foliar application on number of seeds/pod, pod length, thickness and width for broad bean cultivars in 2007/2008 and 2008/2009 seasons.

\begin{tabular}{|c|c|c|c|c|c|c|c|c|}
\hline \multirow[t]{2}{*}{ Cultivars } & \multicolumn{2}{|c|}{$\begin{array}{l}\text { Number of } \\
\text { seeds/pod }\end{array}$} & \multicolumn{2}{|c|}{$\begin{array}{l}\text { Pod length } \\
(\mathrm{cm})\end{array}$} & \multicolumn{2}{|c|}{$\begin{array}{l}\text { Pod thickness } \\
(\mathrm{cm})\end{array}$} & \multicolumn{2}{|c|}{$\begin{array}{l}\text { Pod width } \\
\text { (cm) }\end{array}$} \\
\hline & $\begin{array}{c}2007 / \\
2008 \\
\end{array}$ & $\begin{array}{r}2008 / \\
2009\end{array}$ & $\begin{array}{r}2007 / \\
2008 \\
\end{array}$ & $\begin{array}{c}2008 / \\
2009 \\
\end{array}$ & $\begin{array}{c}2007 / \\
2008\end{array}$ & $\begin{array}{r}2008 / \\
2009 \\
\end{array}$ & $\begin{array}{r}2007 / \\
2008 \\
\end{array}$ & $\begin{array}{c}2008 / \\
2009 \\
\end{array}$ \\
\hline & & \multicolumn{7}{|c|}{ Cultivars } \\
\hline Reinamora (R) & 5.64 & 5.36 & 19.00 & 18.04 & 1.71 & 1.68 & 1.73 & 1.63 \\
\hline Luzudo Otono (L) & 5.21 & 5.16 & 17.17 & 16.69 & 1.74 & 1.66 & 1.68 & 1.60 \\
\hline Akoadolz (A) & 3.41 & 3.25 & 14.01 & 13.62 & 1.65 & 1.56 & 1.36 & 1.35 \\
\hline Ksaseen $7 \quad(K)$ & 3.14 & 3.09 & 10.68 & 10.20 & 1.20 & 1.16 & 1.23 & 1.20 \\
\hline SciabolaVerde(sv) & 6.18 & 6.18 & 22.82 & 21.99 & 1.75 & 1.68 & 1.75 & 1.71 \\
\hline L. S. D 5\% & 0.24 & 0.18 & 0.58 & 0.61 & 0.05 & 0.04 & 0.034 & 0.02 \\
\hline & & & \multicolumn{3}{|c|}{ Treatments } & & & \\
\hline Setter-2 (S) & 4.97 & 4.64 & 16.73 & 16.32 & 1.62 & 1.58 & 1.60 & 1.54 \\
\hline Oraset-x (0) & 4.94 & 4.69 & 17.96 & 17.10 & 1.64 & 1.59 & 1.62 & 1.55 \\
\hline Hyper-k (H) & 4.53 & 4.55 & 16.43 & 15.87 & 1.60 & 1.53 & 1.52 & 1.49 \\
\hline Control (C) & 4.44 & 4.54 & 15.83 & 15.16 & 1.58 & 1.49 & 1.45 & 1.42 \\
\hline L. S. D $5 \%$ & 0.16 & NS & 0.46 & 0.39 & NS & 0.03 & 0.041 & 0.03 \\
\hline & & & \multicolumn{4}{|c|}{ Cultivars $\mathrm{x}$ Treatments } & & \\
\hline $\mathbf{R} \times \mathbf{S}$ & 5.78 & 5.40 & 19.33 & 18.43 & 1.75 & 1.71 & 1.79 & 1.69 \\
\hline $\mathbf{R} \times \mathbf{O}$ & 5.95 & 5.60 & 20.20 & 19.03 & 1.74 & 1.75 & 1.82 & 1.66 \\
\hline $\mathbf{R} \times \mathbf{H}$ & 5.53 & 5.18 & 18.55 & 17.88 & 1.69 & 1.66 & 1.70 & 1.62 \\
\hline $\mathrm{R} \times \mathrm{C}$ & 5.33 & 5.25 & 17.93 & 16.85 & 1.65 & 1.59 & 1.61 & 1.56 \\
\hline LXS & 5.33 & 5.18 & 17.30 & 17.38 & 1.76 & 1.72 & 1.74 & 1.66 \\
\hline LXO & 5.45 & 5.23 & 18.07 & 17.10 & 1.76 & 1.71 & 1.74 & 1.63 \\
\hline LXH & 5.05 & 5.10 & 16.93 & 16.45 & 1.71 & 1.63 & 1.66 & 1.62 \\
\hline LXC & 5.03 & 5.13 & 16.38 & 15.83 & 1.71 & 1.59 & 1.58 & 1.53 \\
\hline A X S & 3.73 & 3.28 & 14.48 & 13.90 & 1.62 & 1.55 & 1.44 & 1.41 \\
\hline A $\times 0$ & 3.58 & 3.25 & 14.30 & 13.98 & 1.73 & 1.64 & 1.41 & 1.43 \\
\hline A X H & 3.18 & 3.25 & 13.70 & 13.30 & 1.63 & 1.54 & 1.31 & 1.34 \\
\hline$A \times C$ & 3.18 & 3.23 & 13.55 & 13.30 & 1.63 & 1.51 & 1.28 & 1.25 \\
\hline KXS & 3.25 & 3.13 & 10.30 & 10.10 & 1.23 & 1.21 & 1.25 & 1.20 \\
\hline K X O & 3.25 & 3.13 & 12.03 & 11.55 & 1.21 & 1.19 & 1.27 & 1.25 \\
\hline KX H & 3.05 & 3.13 & 10.35 & 9.78 & 1.19 & 1.13 & 1.21 & 1.21 \\
\hline $\mathrm{K} \times \mathrm{C}$ & 3.00 & 3.00 & 10.03 & 9.38 & 1.18 & 1.11 & 1.17 & 1.16 \\
\hline s v X S & 6.75 & 6.23 & 22.23 & 21.80 & 1.74 & 1.71 & 1.79 & 1.77 \\
\hline svXo & 6.48 & 6.28 & 25.18 & 23.83 & 1.75 & 1.67 & 1.83 & 1.79 \\
\hline SVXH & 5.85 & 6.10 & 22.60 & 21.93 & 1.79 & 1.71 & 1.74 & 1.68 \\
\hline S V X C & 5.65 & 6.10 & 21.78 & 20.43 & 1.72 & 1.63 & 1.64 & 1.61 \\
\hline L. S. D $5 \%$ & NS & NS & 1.02 & 0.87 & NS & NS & NS & NS \\
\hline
\end{tabular}




\section{Effect of foliar application}

Pod length was significantly increased by foliar application of Oraset-x compared with the control treatment in both seasons. (Table 4). It is evident all tested treatments were more superior compared with control. It could be suggested that improvement in pod characters was noticed by the application of mentioned effective treatment. These results agree with those Helal et al. (2005b). They found that spraying pea plants with some nutrients improved pod characters compared with the control treatment.

\section{Effect of interaction between cultivars and foliar application}

Data in Table (4) indicated that significant differences were found concerning cultivars and foliar application interaction on pod length in both seasons. Spraying Sciabola Verde cultivar with Oraset - $\mathrm{x}$ gave the tallest pod length in both seasons followed by the same cultivar but with the Hyper $-\mathrm{K}$ in both seasons. On the other hand no significant differences in pod thickness and width were detected among the tested cultivars.

\section{Weight of 100 green seed}

\section{Effect of cultivars}

Significant differences were observed in weight of 100 seeds among the five tested broad bean cultivars as shown in Table (5). Reinamora cultivar showed the highest weight of 100 seeds followed by Luzudo Otono cultivar in both seasons.

Differences among cultivars were noticed for weight of 100 green seed were also reported by Farage and Helal (2004) and Helal et al. (2005a).

\section{Effect of foliar application}

Data in Table (5) revealed that weight of 100 green seeds was significantly increased by foliar application of Oraset-x treatment compared with the control treatment in both seasons. It is evident all tested treatments improved weight of 100 seed by the application of mentioned effective treatment. These results confirmed with those of Amer and El Assiouty (2004), Helal (2006), Kamal and Abd Al Gaid (2008) and Ali (2010). They found that spraying leguminous plants with some nutrients substance improved weight of 100 seed compared with the control treatment.

\section{Effect of interaction between cultivars and foliar application}

Data shown in Table (5) showed that significant differences were found for cultivars and foliar application interaction on weight of 100 green seeds in both seasons. The Oraset-x treatment with Reinamora cultivar gave the heaviest weight of 100 green seed followed by spraying Setter- 2 on the same cultivar and Oraset-x on Luzudo Otono without significant differences between them in both seasons. 
Table 5. Effect of some foliar application on weight of 100 seed, total protein and potassium percentage for broad bean cultivars in 2007/2008 and 2008/2009 seasons.

\begin{tabular}{|c|c|c|c|c|c|c|}
\hline \multirow[t]{2}{*}{ Cultivars } & \multicolumn{2}{|c|}{ Weight of 100 seed $(\mathrm{g})$} & \multicolumn{2}{|c|}{$\begin{array}{c}\text { Total } \\
\text { Protein (\%) }\end{array}$} & \multicolumn{2}{|c|}{$\begin{array}{c}\text { Potassium } \\
(\%)\end{array}$} \\
\hline & $\begin{array}{c}2007 / \\
2008\end{array}$ & $\begin{array}{c}2008 / \\
2009\end{array}$ & $\begin{array}{c}2007 / \\
2008\end{array}$ & $\begin{array}{c}2008 / \\
2009\end{array}$ & $\begin{array}{c}2007 / \\
2008\end{array}$ & $\begin{array}{c}2008 / \\
2009\end{array}$ \\
\hline & \multicolumn{4}{|c|}{ Cultivars } & & \\
\hline Reinamora (R) & 191.91 & 188.85 & 23.24 & 22.33 & 3.15 & 3.20 \\
\hline Luzudo Otono (L) & 186.49 & 184.64 & 22.51 & 21.86 & 2.89 & 2.88 \\
\hline Akoadolz (A) & 78.14 & 79.41 & 21.01 & 20.64 & 2.83 & 2.79 \\
\hline Ksaseen $7 \quad$ (K) & 60.50 & 59.65 & 21.77 & 20.83 & 2.68 & 2.67 \\
\hline Sciabola Verde(sv) & 180.89 & 177.36 & 22.48 & 21.54 & 3.16 & 3.19 \\
\hline L. S. D 5\% & 2.08 & 3.33 & 1.14 & 0.96 & 0.21 & 0.14 \\
\hline & \multicolumn{4}{|c|}{ Treatments } & & \\
\hline Setter-2 (S) & 145.13 & 143.59 & 23.57 & 22.82 & 3.11 & 3.11 \\
\hline Oraset-x $\quad(0)$ & 147.57 & 145.02 & 24.19 & 23.10 & 2.93 & 2.94 \\
\hline Hyper-k (H) & 136.13 & 135.01 & 21.92 & 20.94 & 3.12 & 3.17 \\
\hline Control (C) & 129.53 & 128.32 & 19.18 & 18.90 & 2.60 & 2.56 \\
\hline \multirow[t]{2}{*}{ L. S. D 5 \% } & 2.55 & 2.34 & 0.87 & 0.84 & 0.16 & 0.13 \\
\hline & \multicolumn{5}{|c|}{ Cultivars $\mathbf{x}$ Treatments } & \\
\hline $\mathbf{R} \times \mathbf{S}$ & 200.48 & 196.03 & 24.99 & 23.13 & 3.32 & 3.38 \\
\hline $\mathbf{R} \times \mathbf{O}$ & 202.53 & 199.70 & 25.58 & 24.77 & 3.08 & 3.16 \\
\hline $\mathbf{R} \times \mathbf{H}$ & 188.28 & 184.30 & 22.36 & 22.09 & 3.42 & 3.44 \\
\hline $\mathbf{R} \times \mathbf{C}$ & 176.38 & 175.38 & 20.03 & 19.32 & 2.79 & 2.81 \\
\hline LXS & 195.80 & 193.80 & 24.21 & 23.13 & 3.07 & 3.09 \\
\hline LXO & 197.93 & 194.58 & 24.59 & 23.74 & 2.95 & 2.93 \\
\hline LX X H & 181.50 & 180.45 & 21.26 & 20.98 & 3.03 & 3.30 \\
\hline LXC & 170.75 & 169.73 & 20.28 & 19.16 & 2.51 & 2.22 \\
\hline$A \times S$ & 81.60 & 84.93 & 21.80 & 22.28 & 2.94 & 2.88 \\
\hline$A \times 0$ & 85.05 & 85.50 & 22.34 & 21.56 & 2.94 & 2.86 \\
\hline A X H & 74.60 & 75.03 & 20.58 & 19.88 & 2.99 & 2.96 \\
\hline$A \times C$ & 71.30 & 72.10 & 19.31 & 18.83 & 2.48 & 2.45 \\
\hline KXS & 62.88 & 62.03 & 22.39 & 21.67 & 2.82 & 2.92 \\
\hline K X 0 & 63.70 & 62.73 & 23.33 & 22.36 & 2.55 & 2.51 \\
\hline KX H & 58.43 & 57.88 & 22.58 & 20.50 & 2.94 & 2.90 \\
\hline KXC & 57.00 & 55.98 & 18.78 & 18.78 & 2.40 & 2.35 \\
\hline svXs & 184.90 & 181.20 & 24.47 & 23.88 & 3.42 & 3.29 \\
\hline s v Xo & 188.65 & 182.58 & 25.15 & 23.06 & 3.15 & 3.26 \\
\hline S VXH & 177.83 & 177.28 & 22.84 & 21.25 & 3.24 & 3.24 \\
\hline svXc & 172.20 & 168.40 & 17.49 & 17.97 & 2.83 & 2.98 \\
\hline L. S. D $5 \%$ & 5.71 & 5.24 & 1.95 & NS & NS & 0.28 \\
\hline
\end{tabular}




\section{Chemical composition}

\section{Effect of cultivars}

Data in Table (5) show that the contents of total protein were highest in cV. Reinamora followed by Luzudo Otono and Sciabola Verde. Without significant differences among them in both seasons.

Concerning potassium percentage, Reinamora cultivar was superior in potassium contents followed by cv. Sciabola Verde. in both seasons. Similar results were obtained by Crepon et al. (2010) and Patrick and Stoddard (2010). They found that the cultivars of broad bean differ in total protein and potassium percentage.

\section{Effect of foliar application}

Results in Table (5) indicated that foliar spraying on broad bean plants with Oraset-x treatment followed by Setter- 2 treatment increased total protein in the seeds without significant differences between them compared with the other treatment and control in both seasons. Data showed that also foliar spraying with Hyper -K followed by Setter-2 gave the highest values from potassium percentage without significant differences between them compared with other treatment and control in both seasons. The high content of potassium due to Hyper-K and Setter-2 treatments were logically true might be due to known positive effect of potassium on $\mathrm{CO}_{2}$ assimilation and energy metabolism. Herein, it could be suggested that these treatments improved, to large extent, the content of potassium and protein of broad bean. These results confirmed with those Helal et al., (2005b). Ahmed et al., (2006), Helal (2006) and Ali (2010) on leguminous plants increased chemical constituents of the seeds.

\section{Interaction between cultivars and foliar application}

Data in Table (5) revealed that no significant differences were found for cultivars and foliar application interaction on total protein in the second season and on potassium percentage in the first season, while there were significant differences on total protein in the first season and on potassium percentage in second season. Foliar spraying with Oraset-x treatment on cv. Reinamora increased total protein compared with the other treatments in the first season. However, foliar spraying with Hyper $-\mathrm{K}$ treatment on cv. Reinamora gave the highest value of potassium percentage in second season. 


\section{REFERENCES}

1. Abd Allah, E. M. M. 2008. Partial diallel analysis of some economic characters among six parents of broad bean (Visia fabaL.). Egypt J. Appl. Sci. 23 (11) : 225234.

2. Abdel Aziz, M. A. and A. G. Zakher. 2010. Effect of foliar spray with some compounds for improving yield and quality of pea pods (Pisium sativum L.) Egypt. J. Appl. Sci. , 25 (9) : 647-661.

3. Ahmed, M. E. , O. A. H. El Zeiny and M. H. Zaky. 2006. Studies on the effect of vitamin $B_{1}$ and some amino acids on growth yield and chemical copmpsition of bean. Egypt. J. Appl. Sci. 21 (48) : 567-581.

4. Ali, T. G. A. 2010. Physiological studies on growth, seeds yield and its quality of common bean. Ph. D. Thesis, Fac. Agric. Benha Univ., Egypt, 107 p.

5. Amer, S. S. and F. M. M. El Assiouty. 2004. Pea seeds production as affected by foliar application with citric and nofatraim. J. Agric. Sci. Mansoura Univ. 29 (6) 2531-3544.

6. Crepon, K. , P. Marget, C. Peyronnet, B. Carrouiee, P. Arese and G. Duc. 2010. Nutritional value of faba bean seeds for feed and food. Field Crops Res. 115 : 329-339.

7. Ewais, N. A. , I. I. El Oksh, M. M. Soliman and S. M. El Gizy. 2010. Effect of some treatments on tolerance of snap bean plants to early planting dates. Research Bulletin Ain Shams Univ., 1, 2009.

8. Farag, S. T. and F. A. Helal. 2004. Heterosis and combining ability in broad bean (Visia faba L.) Minufiya. J. Agric. Res. 29 (3) : 707-722.

9. Helal, F. A. 2006. Cold tolerance of snape bean plants during early summer season by using some substances to improve quality and yield. Egypt. J. Appl. Sci. $21(12 \mathrm{~A})$ : 93-116.

10. Helal, F. A. , O. A. H. El Zeiny and S. A. El Saaed. 2005 a. Performance of faba bean (Visia faba L.) cultivars and their response to spray with some foliar fertilizers and yeast. Egypt. J. Of Appl. Sci. , 20 (8B) : 555-473.

11. Helal, F. A. ; S. T. Farag and S. A. El Sayed. 2005 b. Studies of growth yield and its components and chemical composition under effect of vitamin C, vitamin $B_{1}$, boric acid and sulpher on pea (Pisium sativum L.) plants. J. Agric. Sci. Mansoura Univ. 30 (6) : 3343-3354.

12. Hesse, P. R. 1971. A Text book of soil chemical analysis (Jhan muttay pupils) London, Great Britation 
13. Jackson, M. L. 1967. Soil chmical Analysis. Prentice Hall of India Private Limited Newdelhi.

14. Kamal, A. M. and M. A. Abd Al Gaid. 2008. Effect of foliar application with some antioxidants on growth and yield of pea (Pisium sativum L.) under early planting conditions. J. Agric. Sci. Mansoura Univ. , 33 (10) : 7413-7420.

15. Patrick, H. W. and F. L. Stoddard. 2010. Physiology of flowering and grain filling in faba bean. Field Crops Research. 115 (3):234-242.

16. Shehata, S. A. , A. H. Hassan, S. M. El Gizy and N. S. Turkey. 2007. Improving metabolic and agronomic performance of bean under high temperature stress condition by using and antioxidants, amino acid and shading of maize. Egypt. J. of Appl. Sci. $22(2 A)$ : $332-350$.

17. Snedecor, G. W. and W. G. Cochran. 1980. Statistical Methods. $7^{\text {th }}$ Ed. Iowa State Univ. Press, Ames, Iowa. 


\section{تاثير بعض مواد الرش على المحصول ومكوناته فى الفول الرومى}

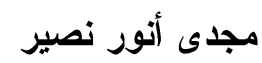

$$
\text { معهز بحوث البساتين - مركز البحوث الزراعبة - الجيزه - مصر }
$$

أجريت هذه التجربة خلال الموسم الثتوى 2008/2007 و 2009/2008 بمحطة بحوث البساتين بالقناطر الخيرية محافظة القليوبية، وذلك لدراسة سلوك واستجابة خمسة اصناف من الفول

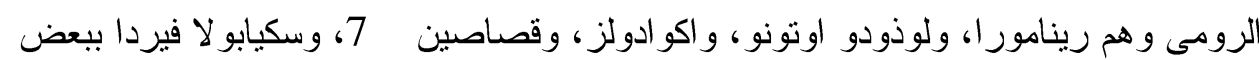

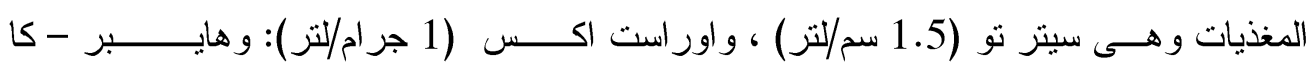

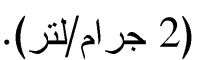

رشت هذه المواد على النباتات أربع مرات لدراسة تاثير ذلك على النمو الخضرى، وسلوك التزهير، و المحصول الكلى الاخضر ، ومو اصفات القرون و المحتوى الكيماوى للبذور. أوضحت النتائج ان الاصناف اختلفت معنويا فى الصفات التاليه : ارتفاع النبات، وعدد

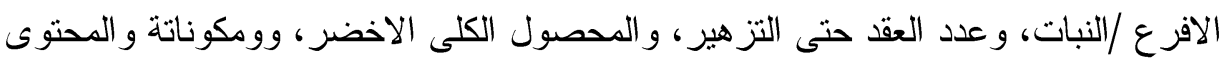

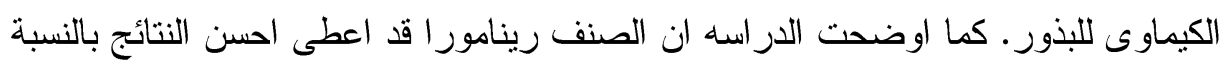

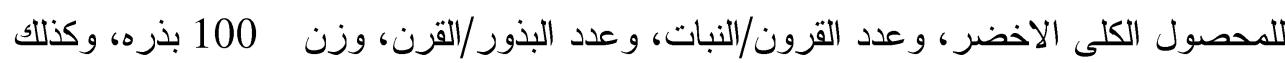
محتوى البروتين.

أدت معاملات الرش الورقى بالمو اد المغذيه الى وجود فرق معنوي على ارتفاع النبات، و عدد

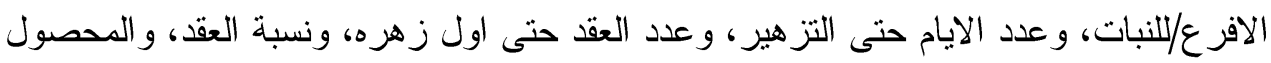

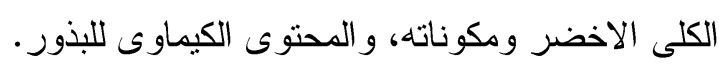

كما أدى الرش الورقى بالمادتين اور است اكس، ويليها سيتز تو الى تفوق معنوى للنمو

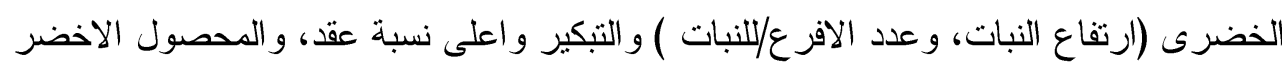

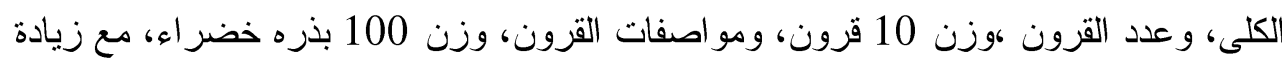

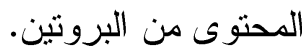

التفاعل بين الاصناف ومعاملات الرش اظهر اختلافات معنويه فى صفات ارتفاع النبات، و عدد الافرع/للنبات، و المحصول الاخضر الكلى، ووزن 10 قرون، وطول القرن، وزن ونس 100 بذره

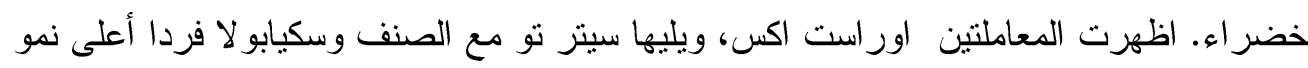

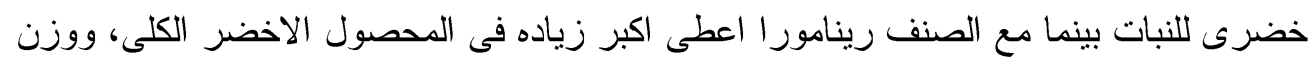
100

توصى الدر اسة باستخدام الرش الورقى بالمادتين اور است اكس، ويليها سيتز نو على اصناف الفول الرومى وذلك لزيادة نسبة العقد و المحصول وجودة القرون. 